\title{
GANGGUAN KESEHATAN PADA ANAK USIA DINI AKIBAT KEKURANGAN GIZI DAN UPAYA PENCEGAHANNYA
}

\author{
Ufiyah Ramlah $^{1}$ \\ ${ }^{1}$ Dosen Fakultas Tarbiyah dan Ilmu Keguruan Institut Agama Islam Negeri Palu
}

\begin{abstract}
ABSTRAK
Kesehatan adalah hal terpenting dan sangat berharga bagi masyarakat pada umumnya untuk mewujudkan kondisi ini, diperlukan asupan gizi yang cukup. Gizi merupakan zat makanan yang apabila dikonsumsi seseorang maka bisa mendatangkan kesehatan.Jadi kesehatan dan gizi sangat berhubungan. Menyiapkan asupan gizi untuk anak usia dini merupakan hal yang penting untuk diperhatikan oleh orangtua. Karena asupan gizi yang diterima anak usia dini akan mempengaruhi proses tumbuh kembang mereka diusia dewasa kelak.Gizi pada anak tidak dapat dipisahkan dan erat kaitannya dengan kesehatan dan kecerdasan anak. Selain itu, melalui gizi yang diterima anak akan menjadi faktor pendukung dari pertumbuhan dan perkembangan anak. Tujuan penelitian ini adalah untuk meningkatkan kesadaran pendidik maupun orang tua tentang pentingnya kecukupan asupan gizi untuk Anak. Metode yang digunakan dalam penelitian ini kajian pustaka hasil dan pembahasan penelitian yang searah dengan program yang akan diterapkan. Melalui penelitian ini diharapkan dapat memberikan pemahaman kepada pendidik ataupun orang tua yang ada di rumah, sebagai bentuk kesadaran pengawasan akan asupan dan kecukupan gizi anak yang juga sebagai salah satu faktor penting pendukung dari pertumbuhan dan perkembangnnya. factor penyebab kurang gizi; 1). Penyebab langsung, Makanan anak dan penyakit infeksi yang mungkin diderita anak. 2). Penyebab tidak langsung, Ketahanan pangan di keluarga, pola pengasuhan anak, serta kesehatan dan kesehatan lingkungan. Upaya pencegahan dini pada anak yang mengalami gizi buruk; dengan prinsip-prinsip sebagai berikut $\left.{ }^{1}: 1\right)$.Upaya perbaikan status gizi ibu sejak masa remaja, 2). Pemenuhan kebutuhan gizi balita yang dimulai dari ejak lahir dengan "standar emas makanan bayi": 3). Penapisan massal untuk menemukan hambatan pertumbuhan dan gizi kurang pada anak usia dini. 4). Perhatian khusus diberikan kepada bayi dan balita dengan factor resiko mengalami kekurangan gizi. 5). Dukungan program terkait. 6). Dukungan lintas sector. 7). Perhatian khusus diberikan kepada balita yang rentan memiliki gizi buruk.
\end{abstract}

Kata Kunci: Gangguan Kesehatan, Anak Usia Dini, Kekurangan Gizi

\section{PENDAHULUAN}

Keberhasilan pembangunan suatu bangsa ditentukan oleh sumber daya manusia (SDM) yang berkualitas yaitu SDM yang memiliki fisik tangguh, mental kuat, kesehatan prima, serta tingkat prestasi baik. Pembangunan dan pembinaan SDM yang berkualitas sangat baik dimulai sejak dini, yaitu saat usia sekolah. Anak usia sekolah merupakan masa peralihan dari anak menjadi dewasa. Terjadi pertumbuhan mental, fisik, dan emosional yang cukup cepat pada masa ini. Anak usia sekolah mulai serius untuk mengeskpresikan ide menjadi lebih objektif dan mulai belajar menerima hal-hal baru dilihat dan didengar.

Setiap anak berhak untuk hidup, tumbuh, berkembang dan berpartisipasi secara wajar, mendapat perlindungan dari kekerasan dan diskriminasi. Mereka juga berhak memperoleh \footnotetext{
2019. 29-31

${ }^{1}$ Pedoman pencegahan dan tatalaksana gizi uruk pada balita, kementerian kesehatan republic Indonesia. Jakarta,
} 
pelayanan kesehatan dan jaminan social sesuai dengan kebutuhan fisik, mental, spiritual dan social. Seperti tercantum dala undang-undang perlindungan anak nomor 23 tahun $2002 .^{2}$

Praktik gizi dan pendidikan gizi merupakan salah satu prioritas utama di negaranegara maju. Kebutuhan gizi anak usia balita (bawah lima tahun) sangat penting, karena pertumbuhan dan perkembangan secara pesat terjadi pada kelompok usia ini ${ }^{3}$, Pemberian gizi seimbang pada periode ini dilakukan untuk mendukung perkembangannya secara optimal. Periode ini bersifat irreversible, yang berarti tidak dapat diperbaiki di fase kehidupan berikutnya dan akan memengaruhi outcome pada masa anak-anak dan dewasa ${ }^{4}$. Idealnya perkembangan anak sejalan dengan pertumbuhan. Kompleksitas sistem jaringan otot, sistem syaraf serta sistem fungsi organ tubuh sejalan dengan proses pematangan fisik atau pertumbuhan. Kekurangan gizi pada anak balita berdampak pada gangguan pertumbuhan yang mengakibatkan gangguan terhadap perkembangan anak ${ }^{5}$. Dengan demikian status gizi sangat menentukan perkembangan di kemudian hari.

Secara global masalah gizi anak balita berdasarkan data berat badan menurut usia $(\mathrm{BB} / \mathrm{U})$, tinggi badan menurut usia $(\mathrm{TB} / \mathrm{U})$, dan berat badan menurut tinggi badan $(\mathrm{BB} / \mathrm{TB})$ masih sangat tinggi dan menjadi tantangan kesehatan terutama bagi negara berkembang ${ }^{6}$

Kondisi kesehatan dan gizi anak usia dini di Indonesia masih memprihatinkan. Pada tahun 2005 jumlah anak 0-6 tahun adalah 27,6 juta anak atau sekitar 27,6 juta anak atau sekitar 12,79 persen dari total penduduk Indonesia. Hanya 25 persen yang terakses program peningkatan kesehatan, gizi. Selain cakupan yang masih rendah, program yang diselenggarakan itu masi terfragmentasi sehingga tidak menyentuh kebutuhan tumbuh kembang anak secara holistic. Rendahnya cakupan dan kualitas penyelenggaraan program penyelenggaraan anak usia dini mengakibatkan konsidisi anak Indonesia masih memprihatinkan yang ditunjukkan dengan rendanya derajat kesehatan gizi dan pendidikan. Berdasarkan data kementerian perencanaan pembangunan nasional (BAPPENAS) pada tahun 2018 mencatat ada 9 juta anak di Indonesia yang mengalami stunting ${ }^{7}$.

Rendahnya derajat, gizi dan pendidikan pada anak usia dini lebih banyak terjadi pada anak yang berasal dari keluarga tidak mampu dan yang tinggal di wilayah pedesaan serta di wilayah dengan penyediaan layanan social dasar yang tidak memadai. Memberikan pelayanan kesehatan tidak cukup untuk memperbaiki kesehatan mereka, tapi yang paling penting adalah memperbaiki kondisi keluarganya.

\section{METODE PENELITIAN}

Penelitian ini menggunakan kajian pustaka. Kajian pustaka dalam suatu penelitian ilmiah adaalah salah satu bagian yang pertama serta merupakan langkah yang penting dari keseluruhan langkah-langkah metode penelitian. Marzali (2016) menjelaskan bahwa kajian pustaka atau kajian literature adalah satu penelusuran dan penelitian kepustakaan dengan

\footnotetext{
${ }^{2}$ Pedoman pencegahan dan tatalaksana gizi uruk pada balita, kementerian kesehatan republic Indonesia. Jakarta, 2019.

${ }^{3}$ Program Studi Gizi, Fakultas Kedokteran dan Ilmu Kesehatan, Universitas Kristen Satya Wacana. Jl. Kartini No.11 A, Salatiga, Jawa Tengah 50711, Indonesia.

${ }^{4}$ Departemen Gizi Masyarakat, Fakultas Ekologi Manusia, Institut Pertanian Bogor. Jl. Lingkar Kampus, Kampus IPB Dramaga, Bogor, Jawa Barat 16680, Indonesia.

${ }_{6}^{5}$ Jurnal Gizi Indonesia (The Indonesian Journal of Nutrition), 8 (2), 2020, 143

${ }^{6}$ Kementerian Kesehatan RI. Laporan Nasional HasilRiset Kesehatan Dasar 2018. Jakarta: Kemenkes RI; 2018.

${ }^{7}$ Detik news, 9 juta anak kekurangan gizi. Retrieved from https//.mdetik.com
} 
membaca berbagai buku, jurnal, dan terbitan-terbitan lain yang berkaitan dengan topik penelitian, untuk menghasilkan satu tulisan berkenaan dengan satu topik atau isu tertentu. Tujuan metodologi kajian literatur ini digunakan adalah sebagai kepentingan dari penelitian. Dengan mempelajari, menganalisis, dan membandingkan kajian peneliti lain guna menciptakan sesuatu yang baru metode kajian pustaka atau kajian literature pengambilan data dan hasil pembahasan didapat dari kajian pustaka yang masuk ke dalam jenis data sekunder, yaitu pengumpulan data atau pengumpulan hasil dari pembahasan penelitian lain yang sejalan dengan penelitian yang dilakukan serta membuat analisis kesimpulan.

\section{HASIL DAN PEMBAHASAN}

\section{A. Faktor Gangguan Kesehatan Anak Usia Dini}

Faktor penyebab terganggunya kesehatan anak usia dini:

1. Penyebab langsung

Makanan anak dan penyakit infeksi yang mungkin diderita anak. Timbulnya gizi kurang tidak hanya karena makanan yang kurang, tetapi juga karena penyakit. Anak yang mendapatkan makanan cukup baik, tetapi sering diserang diare atau demam, akhirnya dapat menderita kurang gizi. Demikian juga pada anak yang makan tidak cukup baik, maka daya tahan tubuhnya akan melemah. Dalam keadaan demikian mudah diserang infeksi yang dapat mengurangi nafsu makan, dan akhirnya dapat menderita kurang gizi. Pada kenyataannya keduanya baik makanan dan penyakit infeksi secara bersama-sama merupakan penyebab kurang gizi.

2. Penyebab tidak langsung

Ketahanan pangan di keluarga, pola pengasuhan anak, serta kesehatan dan kesehatan lingkungan ${ }^{8}$. Secara medik, indikator yang dapat digunakan untuk menyatakan masalah gizi adalah indikator antropometri (ukurannya adalah kadar hemoglobin dalam darah) dan sebagainya diluar aspek medik, masalah gizi dapat diakibatkan oleh kemiskinan, social budaya, kurangnya pengetahuan dan pengertian, pengadaan dan distribusi pangan, dan bencana alam (Khumaidi,1994).

Adapun faktor masalah gizi pada anak:

a. Masalah gizi karena kemiskinan indikatornya taraf ekonomi keluarga dan ukuran yang dipakai adalah garis kemiskinan.

b. Masalah gizi karena sosial budaya indikatornya adalah stabilitas keluarga dengan ukuran frekuensi nikah-cerai-rujuk, anak-anak yang dilahirkan di lingkungan keluarga yang tidak stabil akan sangat rentan terhadap penyakit gizi-kurang. Juga indikator demografi yang meliputi susunan dan pola kegiatan penduduk.

c. Masalah gizi karena kurangnya pengetahuan dan keterampilan dibidang memasak, konsumsi anak, keragaman bahan, dan keragaman jenis masakan yang mempengaruhi kejiwaan, misalnya kebosanan.

d. Masalah gizi karena pengadaan dan distribusi pangan, indikator pengadaan pangan (food supply) yang biasanya diperhitungkan dalam bentuk neraca bahan pangan, diterjemahkan ke dalam nilai gizi dan dibandingkan dengan nilai rata-rata

\footnotetext{
${ }^{8}$ Hariza Adnani,2011.Ilmu Kesehatan Masyarakat.Yogyakarta Nuha Medika. Indriani, R, Mesiono, Sapri. (2019). Intensitas Asupan Gizi dalam Mengembangkan Kesehatan Anak Usia 5-6 Tahun di TK Ummi Erni Desa Pematang Johar. Jurnal Raudhah. Vol 7 (2). 35 - 48.
} 
kecukupan penduduk.Gizi merupakan salah satu kehidupan manusia yang erat kaitannya dengan kualitas fisik maupun mental manusia. Keadaan gizi meliputi proses penyediaan dan penggunaan gizi untuk pertumbuhan, perkembangan, dan pemeliharaan serta aktivitas. Keadaan kurang gizi dapat terjadi akibat ketidak seimbangan asupan zat- zat gizi, faktor penyakit pencernaan, absorbsi, dan penyakit infeksi.Departemen Kesehatan RI menyatakan bahwa masalah gizi di Indonesia masih didominasi oleh kekurangan zat gizi yang disebabkan oleh banyak faktor,diantaranya adalah tingkat sosial ekonomi keluarga ${ }^{9}$. Krisis ekonomi yang melanda sejak 1997, telah menambah jumlah keluarga miskin dengan daya beli yang rendah, sehingga memberikan dampak terhadap penurunan kualitas hidup keluarga dan meningkatkan jumlah anak-anak yang kekurangan gizi.Selain ketersediaan pangan, masalah gizi juga dipengaruhi oleh faktor perilaku ibu, dukungan keluarga, dan petugas kesehatan.

Menurut Green (1980), masalah perilaku kesehatan dipengaruhi oleh 3 faktor utama. yaitu faktor yang mempermudah (predisposing factors) mencakup: pengetahuan, sikap, presepsi,nilai-nilai dan norma dalam masyarakat yang berkaitan dengan kesehatan; faktor pendorong (enabling factors) meliputi ketersediaan sarana dan prasarana atau fasilitas kesehatan bagi masyarakat, dimana fasilitas ini pada hakikatnya mendukung atau memungkinkan terwujudnya perilaku kesehatan, dan faktor ketiga berupa faktor penguat (reinforcing factors) meliputi sikap dan perilaku tokoh masyarakat, tokoh agama, dan juga sikap, perilaku, dan ketrampilan petugas kesehatan.

Menurut Achmad Djaeni (2009), penyebab langsung dari gizi kurang adalah konsumsi kalori dan protein yang kurang. Sebab tidak langsung ada beberapa yangdominan, yaitu ekonomi negara yang kurang, pendidikan umum dan pendidikan gizi yang rendah, produksi pangan yang tidak mencukupi, kondisi hygiene yang kurang baik, dan jumlah anak yang terlalu banyak. Sebab antara adalah pekerjaan yang rendah, penghasilan yang kurang, paska panen, sistem perdagangan, dan distribusi yang tidak lancar dan tidak merata.Menurut Soegeng santoso dan Anne (2009), masalah gizi yang terjadi pada anak bisa dikaitkan dengan masalah makan anak. Ada beberapa pendapat mengenai penyebab kesulitan mana anak, menurut Palmer dan Horn antara lain adalahkelainan neuro-motorik, kelainan kongenital, kelainan gigi-geligi, penyakit infeksi menahun, defisiensi nutrien, dan psikologik. Untuk faktor kelainan psikologik disebabkan oleh kekeliruan orang tua dalam hal mengatur makan anaknya. Ada orang tua yang bersikap terlalu melindungi dan ada orang tua yang terlalu memaksakan anaknya makan terlalu banyak melebihi keperluan anaknya. Juga apabila anak jauh dari ibunya, dapat terjadi tidak ada nafsu makan. Perasaan takut berlebih pada makanan juga dapat mengakibatkan anak tidak mau makan.

${ }^{9}$ Departemen Gizi dan Kesehatan Masyarakat FKM UI.Gizi dan Kesehatan Masyarakat.jakarta : PT Raja Grafindo Persada, 2010. 


\section{B. Mengenali Dan Menangani Gangguan Kesehatan Pada Anak Usia Dini}

Berikut beberapa tanda gangguan kesehatan yakni:

1. Mudah merasa lelah dan letih.

2. Tubuh terlalu kurus atau gemuk.

3. Nafsu makan menurun.

4. Memiliki gangguan berbicara

5. Memiliki kesulitan melihat dalam jarak jauh.

\section{Kurang Gizi/ Malnutrisi}

Banyak anak kekurangan gizi karena mereka tidak mendapatkan cukup makanan. Atau jika mereka hanya mendapatkan makanan yang kurang kandungan gizinya, misalnya makanan dengan banyak air dan serat di dalamnya, seperti ubi kayu, talas akar, atau bubur jagung. Makanan jenis ini hanya membuat anak-anak menjadi kenyang dan tidak memenuhi kebutuhan zat gizi untuk pertumbuhannya ${ }^{10}$. Kadang-kadang pada anak ditemukan kekurangan zat-zat gizi tertentu, seperti kekurangan vitamin A, yodium, dan lain-lain. Malnutrisi dapat menyebabkan berbagai masalah pada anak, termasuk dalam kasus ringan seperti:

1) pertumbuhan lambat

2) perut bengkak

3) tubuh kurus

4) kehilangan nafsu makan

5) kehilangan energi

6) pucat (anemia)

7) luka di sudut-sudut mulut

8) sering pilek dan infeksi lainnya

9) rabun ayam

Dalam kasus lain yang lebih serius, yaitu:

1) berat badan tidak bertambah

2) pembengkakan kaki (kadang-kadang muka juga)

3) bintik hitam, 'memar', atau buka mengupas luka

4) rambut menipis atau bahkan rontok

5) kurangnya keinginan untuk tertawa atau bermain

6) luka dalam mulut

7) kecerdasan tidak berkembang

8) 'Mata kering' (xeroftalmia)

9) kebutaan

Mencegah dan mengobati masalah kekurangan gizi pada anak-anak sebenarnya cukup mudah, yaitu dengan memberikan makanan bergizi secara cukup, atau cobalah untuk memberinya lebih banyak / sering makan. Selain itu penambahan (fortifikasi) zat-zat nutrisi esensial misalnya zat besi, kalsium, vitamin, protein dll pada makanan juga sangat baik untuk

\footnotetext{
${ }^{10} \mathrm{http} / /$ yanamustakim.blogspot.com
} 
memenuhi kekurangan zat tersebut. Usahakan selalu berpedoman pada pola gizi seimbang dalam memenuhi makan anak-anak.

Beberapa masalah gangguan kesehatan pada anak usia dini:

1. Gangguan psikis

Gangguan psikologis pada anak meliputi perubahan emosi, fungsi fisik, perilaku dan kinerja mental. Permasalahan gangguan psikologis tersebut dapat disebabkan oleh faktorfaktor seperti gaya pengasuhan, masalah keluarga, kurangnya perhatian, penyakit kronis atau cedera, dan rasa kehilangan. Anak biasanya tidak langsung bereaksi ketika masalah terjadi, tetapi akan menunjukkan reaksi kemudian hari. Bimbingan yang tepat dapat membantu anak dapat mempersiapkan diri jika dihadapkan pada masalah yang sifatnya traumatis pada anak. Orang tua harus dapat memotivasi anak agar lebih ekspresif menghadapi ketakutan dan kecemasannya.Beberapa gangguan psikis pada anak adalah gangguan emosi, belajar, sosial, psikiatri, dan khusus.

\section{Gangguan Perilaku}

Perilaku tertentu adalah normal terjadi pada anak-anak pada usia dini, tetapi jika masih tetap berlanjut hingga kemudian hari mungkin mengundang intervensi. Gangguan perilaku pada anak dapat ditunjukkan seperti suka melampiaskan amarah karena frustrasi atau kesal terhadap suatu hal. Orangtua bisa mengontrol perilaku anak dengan menjauhkan anak dari hal-hal yang membuat anak bertindak demikian. Sementara perilaku anak yang mencuri atau berbohong mungkin umum pada tahap awal perkembangannya, pastikan kebiasaan tersebut tidak berlanjut.

\section{Gangguan Tidur}

Masalah tidur termasuk jam tidur yang terlalu banyak atau terlalu sedikit pada anak. Gangguan saat tidur pada tahap petumbuhan mungkin memiliki efek yang merugikan pada kemampuan kognitif anak. Orang tua harus mendorong anak untuk tidur pada waktu yang teratur setiap harinya.

\section{Gangguan kecemasan}

Kecemasan dan ketakutan normal terjadi pada anak dalam masa perkembangan, tetapi jika terus berlanjut dalam waktu yang lama, mungkin akan melumpuhkan kondisi sosial anak. Gangguan kecemasan dapat dikelola dengan cara mengobati kondisi kejiwaan anak seperti terapi keluarga

\section{Diare atau disentri}

Diare pada anak dapat ditandai dengan frekuensi buang air besar lebih dari 4 kali pada bayi dan lebih dari 3 kali pada anak. Bahaya terbesar bagi anak-anak dengan diare adalah dehidrasi, atau kehilangan terlalu banyak cairan dari tubuh. Hal ini akan bertambah bahaya jika disertai muntah-muntah. Bayi dan balita yang diare membutuhkan lebih banyak cairan untuk mengganti cairan tubuh yang hilang melalui tinja dan muntah. Pemberian cairan yang tepat dengan jumlah memadai merupakan modal utama mencegah dehidrasi. Cairan harus diberikan sedikit demi sedikit dengan frekuensi sesering mungkin. Oralit merupakan rumus manjur untuk mengatasi diare pada anak. Jika anak dalam masa pemberian ASI, lanjutkan pemberian ASI, tetapi juga perlu ditambahkan cairan / minum agar tidak mengalami dehidrasi. Bahaya besar kedua untuk anak-anak yang terkena diare adalah kekurangan gizi. Berikan anak makanan bergizi. 


\section{Demam}

Anak dikatakan demam jika suhu tubuhnya melebihi dari $37,5^{\circ} \mathrm{C}$ waktu diukur dengan termometer. Pada anak-anak kecil, demam tinggi (lebih dari $39^{\circ} \mathrm{C}$ ) dapat dengan mudah menyebabkan kejang atau kerusakan otak. Untuk menurunkan demam, dapat dilakukan beberapa hal berikut.

a) Kompres dengan air hangat

Anak dikompres dengan handuk yang dibasahi dengan dibasahi air hangat $\left(30^{\circ}\right.$

C) kemudian dilapkan seluruh badan. Penurunan suhu tubuh terjadi saat air menguap dari permukaan kulit. Oleh karena itu, anak jangan "dibungkus" dengan lap atau handuk basah atau didiamkan dalam air karena penguapan akan terhambat. Tambah kehangatan airnya bila demamnya semakin tinggi. Dengan demikian, perbedaan antara air kompres dengan suhu tubuh tidak terlalu berbeda. Jika air kompres terlalu dingin akan mengerutkan pembuluh darah anak. Akibatnya, panas tubuh tidak mau keluar. Anak jadi semakin menggigil untuk mempertahankan keseimbangan suhu tubuhnya.

b) Berikan obat pereda demam

Perawatan paling efektif untuk demam adalah menggunakan obat penurun panas seperti parasetamol atau ibuprofen. Terdapat berbagai macam sediaan di pasaran seperti: tablet, drops, sirup, dan suppositoria. Pengobatan ini dapat mengurangi ketidaknyamanan anak dan menurunkan suhu 1 sampai $1,5^{\circ} \mathrm{C}$. Sedangkan Aspirin tidak direkomendasikan untuk anak di bawah 18 tahun karena dapat menyebabkan efek samping penyakit serius yang disebut sindrom reye, meskipun angka kejadian penyakit ini jarang.

c) Berikan banyak cairan

Demam pada anak dapat meningkatkan risiko terkena dehidrasi (kekurangan cairan). Tanda dehidrasi paling mudah adalah berkurangnya kencing dan air kencing berwarna lebih gelap daripada biasanya. Maka dari itu, orang tua sebaiknya mendorong anak untuk minum cairan dalam jumlah yang memadai. Anak dengan demam dapat merasa tidak lapar dan sebaiknya tidak memaksa anak untuk makan. Cairan seperti susu (ASI atau sapi atau formula) dan air harus tetap diberikan atau bahkan lebih sering. Anak yang lebih tua dapat diberikan sup atau buah-buahan yang banyak mengandung air. Bila anak tidak mampu atau tidak mau minum dalam beberapa jam, orang tua sebaiknya diperiksakan ke dokter.

d) Istirahat yang cukup

Demam menyebabkan anak lemah dan tidak nyaman. Orang tua sebaiknya mendorong anaknya untuk cukup istirahat. Sebaiknya tidak memaksa anak untuk tidur atau istirahat atau tidur bila anak sudah merasa baikan dan anak dapat kembali ke sekolah atau aktivitas lainnya ketika suhu sudah normal dalam 24 jam. 


\section{Kejang}

Penyebab dari kejang pada anak-anak antara lain demam tinggi, dehidrasi, epilepsi, dan meningitis. Jika anak mengalami demam tinggi, segera redakan agar tidak kejang. Periksa tanda-tanda dehidrasi dan meningitis. Kejang yang datang tiba-tiba tanpa demam atau tanda lainnya mungkin epilepsi, terutama jika anak tampak biasa-biasa saja tanpa menunjukkan ada gejala yang aneh. Kejang yang dimulai pada rahang dan kemudian seluruh tubuh menjadi kaku mungkin akibat tetanus. Tanda-tanda kejang pada anak, di antaranya:

a) Kedua kaki dan tangan kaku disertai gerakan-gerakan kejut yang kuat dan kejang kejang selama 5 menit dan bola mata berbalik ke atas,

b) Gigi terkatup,

c) Muntah,

d) Tak jarang si anak berhenti napas sejenak,

e) Pada beberapa kasus tidak bisa mengontrol pengeluaran buang air besar/ kecil,

f) Pada kasus berat, anak kerap tak sadarkan diri. Adapun intensitas waktu kejang juga sangat bervariasi, dari beberapa detik sampai puluhan menit.

\section{Meningitis}

Penyakit berbahaya ini bisa datang sebagai komplikasi dari campak, gondok, atau yang lain yang serius penyakit. Anak-anak dari ibu yang memiliki TB mungkin mendapatkan meningitis TBC. Seorang anak yang sangat sakit yang terletak dengan cara kepala miring kembali, yang leher terlalu kaku untuk membungkuk ke depan, dan yang tubuhnya membuat gerakan aneh (kejang) mungkin memiliki meningitis.

Gejala yang khas dan umum ditampakkan oleh penderita meningitis diatas umur 2 tahun adalah demam, sakit kepala dan kekakuan otot leher yang berlangsung berjam-jam atau dirasakan sampai 2 hari. Tanda dan gejala lainnya adalah photophobia (takut/menghindari sorotan cahaya terang), phonophobia (takut/terganggu dengan suara yang keras), mual, muntah, sering tampak kebingungan, kesusahan untuk bangun dari tidur, bahkan tak sadarkan diri.

Pada bayi gejala dan tanda penyakit meningitis mungkin sangatlah sulit diketahui, namun umumnya bayi akan tampak lemah dan pendiam (tidak aktif), gemetaran, muntah dan enggan menyusui. Meningitis yang disebabkan oleh virus dapat ditularkan melalui batuk, bersin, ciuman, bertukar alat makan, dan pemakaian sikat gigi bersama. Mencuci tangan yang bersih sebelum makan dan setelah ke toilet umum, memegang hewan peliharaan. Menjaga stamina (daya tahan) tubuh dengan makan bergizi dan berolahraga yang teratur adalah sangat baik menghindari berbagai macam penyakit. Pemberian imunisasi vaksin meningitis merupakan tindakan yang tepat terutama di daerah yang diketahui rentan.

\section{Anemia}

Tanda-tanda umum timbulnya anemia pada anak-anak, antara lain:

a) pucat, terutama di dalam kelopak mata, gusi, dan kuku

b) lemah dan cepat lelah

c) tampak seperti malnutrisi

d) glositis berat (radang lidah disertai rasa sakit)

e) diare dan kehilangan nafsu makan 
Adapun penyebabnya antara lain:
a) kurang zat besi
b) infeksi usus kronis
c) cacing tambang
d) malaria

Berikut adalah cara pencegahan dan pengobatan.

a) Makanlah makanan yang kaya zat besi seperti daging dan telur, kacang, lentil, kacang tanah (kacang tanah), dan gelap hijau sayuran juga memiliki beberapa besi.

b) Seringkali dijumpai adanya cacing tambang pada anak anemia.

c) Jika anda mencurigai adanya cacing tambang, periksakan feses anak di laboratorium. Jika ditemukan telur cacing tambang, segera lakukan pengobatan untuk mengusir cacing tambang ini.

d) Jika perlu, berikan garam besi dengan mulut (ferro sulfat).

e) Jangan memberikan zat besi dalam bentuk tablet untuk bayi atau anak kecil karena bisa menyebabkan keracunan. Sebaiknya berikanlah zat besi berupa cairan. Atau menghancurkan tablet tersebut menjadi bubuk dan mencampurnya dengan makanan.

10. Cacing dan parasite lain

Jika salah satu anak dalam keluarga diketahui menderita cacingan, semua anak dalam keluarga harus dirawat atau diobati untuk memastikan hilangnya cacing. Untuk mencegah infeksi cacing, anak-anak harus:
a) Jagalah kebersihan
b) Gunakan jamban.
c) Jangan bertelanjang kaki.
d) Jangan makan daging mentah atau ikan mentah atau yang setengah matang.
e) Minum hanya air rebus atau murni.

Gangguan kesehatan,walau hanya gangguan kecil dapat menghambat belajar anak,misalnya diare,diare akan membuat badan si anak lemasdan tidak akan sedikit yang mengantarkan mereka pada kematian karena kekurangan cairan.Gizi yang juga akan mengganggu kesehatan anak,jika gizi yang buruk terjadi pada anak usia dini,maka akan mengakibatkan terganggunya kinerja otak bahkan mengurangi kapasitas kecerdasan anak. Bukan berarti makanan yang enak itu dapat memenuhi gizi seimbang,tetapi makanan dengan gizi seimbang adalah makanan yang mengandung karbohidrat,protein,lemak,vitamin,dan mineral dengan kadar yang sesuai dengan kebutuhan tubuh anak.

Tingkat konsumsi makanan ditentukan oleh kualitas serta kuantitas hidangan,susunan hidangan harus memenuhi kebutuhan tubuh,baik dari kualitas maupun kuantitasnya,makan yang berlebihan atau kekurangan makanan maka akan memberikan kodisi kesehatan dan gizi yang tidak seimbang sehingga akan muncul berbagai penyakit seperti obesitas,pennyakit gizi kurang,penyakit metabolik bawaan,penyakit keracunan makanan.Kesehatan si anak sangatlah penting untuk itu kita sharus benar-benar jeli dalam memilih makanan. 


\section{Pentingnya Gizi Untuk AUD}

Usia dini atau biasa disebut dengan masa golden age adalah usia anak pada masa masa awal hidupnya di dunia,dalam masa ini anak berada pada rentang usia 0-5 tahun.pada masa ini,pertumbuhan dan perkembangan anak mengalami peningkatan yang sangat pesat.Terutama dalam pertumbuhan dan perkembangan otak anak.Oleh karena itu,sebagai orang tua harus lebih memperhatikan tumbuh kembang anak secara cermat agar sedini mungkin dapat terdeteksi apa bila terjadi hal-hal yang tidak diinginkan.

Pertumbuhan otak pada anak usia dini sangatlah berpengaruh pada tumbuh kembang anak.Setiap anak di lahirkan dengan sepuluh miliyar sel saraf di otaknya.Sel- sel anak akan terus bertambah untuk memupuk neuron pada usia 3 tahun pertama sejak dilahirkan.Dalam otak,sel-sel saraf akan membentuk ribuan sambungan atau unit-unit antar neuron.Pada saat lahir,berat otak bayi sebesar $25 \%$ dari otak orang dewasa. Dan pada tahun ke dua,otak bayi akan bertambah menjadi $75 \%$ dari otak orang dewasa serta otak kirinya lebih berfungsi dari pada otak kanannya. Salah satu komponen yang perlu dipersiapkan adalah asupan gizi untuk anak usia dini, karena dalam nutirisi terdapat kebutuhan zat gizi yang dibutuhkan untuk pertumbuhan dan perkembangan ${ }^{11}$.

Dalam masa ini membutuhkan gizi serta stimulasi yang baik dan harus terpenuhi secara optimal.Dalam pertumbuhan dan perkembangannya.Oleh karena itu,anak perlu mendapatkan gizi yang cukup sejak usia dini seperti diberikannya ASI exsklusif sejak ia di lahirkan sampai minimal ia berusia 6 bulan. Peran ASI sangatlah besar dalam tumbuh kembang bayi,dikarenakan ASI memiliki berbagai kandungan nutrisi antara lain seperti protein,lemak,karbohidrat,mineral,dan vitamin.

Selain itu,Anak juga perlu mendapatkan stimulasi guna untuk mrangsang perkembangan otaknya.Stimulasi dapat di berikan dalam berbagai bentuk yang sederhana,simple,dan mudah untuk di lakukan.seperti halnya dengan cara sentuhan,mengajak anak bermain,bersosialisai,dsb.

Namun,jika pada masa golden age anak tidak dapat terpenuhi kebutuhan zat gizinya,maka hal tersebut akan mengganggu atau memperlambat pertumbuhan dan perkembangannya,seperti pada perkembangan fisik dan mentalnya,sel-sel otaknya,dsb. Hal inilah yang nantinya akan berdampak pada kehidupan anak dikemudian hari.

Pada usia 18 bulan, biasanya anak akan sulit makan. Anak suka memilih dan rewel dalam hal makanan. Anak mungkin akan rakus makan pada suatu hari namun esok harinya tidak mau makan sama sekali. Dalam memilih makanan anak dopengaruhi oleh beberapa factor, seperti rasa, jumlah dan cara penyajian.

Kebiasaan makan akan mulai terbina pada usia 2-3 tahun. Ada beberapa hal yang yang perlu diperhatikan oleh orang tua untuk memenuhi kebutuhan gizi pada anak, yaitu ${ }^{12}$ :

1. Biasakan anak dan seluruh anggota keluarga memakan makanan gizi seimbang setiap hari, seperti; nasi, lauk pauk, sayur dan buah

2. Tidak memaksa anak untuk makan tapi jadikanlah waktu makan sebagai saat yang menyenangkan

\footnotetext{
${ }^{11}$ Titah nurul lathifah tahar, Status gizi balita. Jurnal ilmiah kesehatan 7 (1), 2018. 1-8.

${ }^{12}$ Mengembangkan perilaku sehat pada anak usia 2-4 tahun, direktorat pembinaan pendidikan anak usia dini. Direktorat jenderal pendidikan anak usia dini. Kementerian pendidikan nasional tahun 2011. 22-24
} 
3. Jangan gunakan waktu makan untuk disipilin apalagi bertengkar

4. Jangan menyuruh anak makan setelah dia bermain aktif, karena ia tidak akan bisa duduk diam ketiaka makan dan akan menjadi geliasah.

5. Perhatikan cara penyajian makanan. Berikan porsi makan sedikit demi sedikit

6. Bagi anak tidaklah penting berapa jumlah yang ia makan tetapi yang penting adalah apa yang ia makan

7. Anak-anak menyukai sajian makanan yang disiapkan dipiring atau mangkok dan sendok yang sama (ia sukai) setiap makan

8. Selera dan pilihan makanan anak tidak menentu. Anak mungkijn mau memakan makanan yang sama selama 3 hari berturut-turut setelah itu ia tidak mau makan lagi.

\section{Pencegahan dini gizi buruk pada anak usia dini}

Dalam upaya menangani masalah gizi buruk dan gizi kurang pada balita, kementerian kesehatan telah menetapkan kebijakan yang komprehensif meliputi pencegahan, edukasi, dan penanggulangan balita gizi buruk. Penanggulangan dilakukan dengan pemberian makanan tambahan (PMT) sedangkan balita gizi buruk harus mendapatkan perawatan sesuai tatalaksana balita gizi buruk yang ada ${ }^{13}$.

Terkadang kesehatan tubuh bisa terganggu,misalkan dari pola makan yang salah atau asupan nutrisi dalam tubuh kurang baik.

Kriteria anak gizi buruk ${ }^{14}$ :

1. Gizi buruk tanpa komplikasi :
a. BB/TB: <-3 SD
b. Terlihat sangat kurus
c. Adanya edema
d. LILA $<11.5 \mathrm{~cm}$ untuk anak 6-59 bulan

2. Gizi buruk dengan komplikasi:

Gizi buruk degan tanda-tanda tersebut disertai salah satu atau lebih dari tanda komplikasi medis berikut:
a. Anoreksia
b. Pneumonia berat
c. Anemia berat
d. Dehidrasi berat
e. Demam sangat tinggi
f. Penurunan kesadaran

Gizi buruk pada anak usia dini merupakan masalah kesehatan masyarakat yang kompleks. Akar masalahnya terkait dengan ketahan pangan dan gizi, kemiskinan, pendidikan, keamanan, ketersediaan air bersih dan sanitasi lingkungan.

Upaya pencegahan gizi kurang pada anak usia dini perlu dilakukan sedini mungkin dengan prinsip-prinsip sebagai berikut ${ }^{15}$ :

1. Upaya perbaikan status gizi ibu sejak masa remaja, yang dilanjukan dengan:

\footnotetext{
${ }^{13}{ }^{13}$ Pedoman pelayanan anak gizi buruk, Kementerian Kesehatan Republik Indonesia, 2011

${ }^{14}$ Pedoman pelayanan anak gizi buruk, kementerian kesehatan repu blik indonesia, 2011. 3

${ }^{15}$ Pedoman pencegahan dan tatalaksana gizi uruk pada balita, kementerian kesehatan republic Indonesia. Jakarta, 2019. 29-31
} 
a. Upaya peningkatan kesehatan ibu sebelum hamil. Antara lain; menghindari hamil terlalu muda, terlalu tua, terlalu dekat jarak kehamilan dan terlalu banyak anak.

b. Penerapan pola hidup sehat, antara lain dengan memenuhi kebutuhan gizi ibu pada masa kehamilan dan ifas. Pelayanan antenatal sesuai dengan standar, termasuk konseling tentang kebutuhan gizi, tidak terpapar asap rokok, , memberikan kolostrum pada bayinya dengan melakukan inisiasi menyusu dini yang diteruskan dengan ASI ekslusif, serta melakukan stimulasi pada bayi sejak dalam kandungan.

2. Pemenuhan kebutuhan gizi balita yang dimulai dari ejak lahir dengan "standar emas makanan bayi":

a. Inisiasi menyusui dini ( $<1$ jam setelah lahir)

b. ASI eksklusif dalam 6 bulan pertama kehidupan

c. Makanan pendamping ASI muali diberikan pada usia 6 bulan dan diberikan secara tepat dan benar

d. ASI dilanjutkan sampai anak berusia 2 tahun atau lebih

3. Penapisan massal untuk menemukan hambatan pertumbuhan dan gizi kurang pada anak usia dini ditingkat masyarakat dilakukan secara berkala pada bulan penimbangan dengan target cakupan penapisan 100\%. Bila ditemukan masalah maka bayi dirujuk ke petugas yang kompeten.

4. Perhatian khusus diberikan kepada bayi dan balita dengan factor resiko mengalami kekurangan gizi, misalnya:

a. Bayi yang dilahirkan dari ibu dengan kurang energy kronis dana tau ibu usia remaja, bayi yang lahir pematur, kembar, lahir dengan kelainan bawaan.

b. Balita dengan infeksi kronis atau infeksi akut berulang dan adanya sumber penularan penyakit dari dalam atau luar rumah

c. Balita yang berasala dari keluarga yang berstatus sosio ekonomi kurang

d. Balitas berkebutuhan khusus

e. Balita yang berada dilingkungan yang terkendala air bersih dan sanitasi yang buruk

Semua balita dipantau pertumbuhannya secara rutin terutama balita denagn factor resiko. Orangtua/ pengasuh diberikan konseling pemberian makan sesuai usia, diberi pelayanan lainnya dan tindak lanjut sedini mungkin untuk mengatasi masalah yang ditemukan.

5. Dukungan program terkait

Hal ini diperlukan dalam upaya pemenuhan total cakupan pelayanan, konseling pemberian makan sesuai umur damn penanganan balita sakit secara komprehensif, serta promosi perubahan perilaku menuju pola hidup bersih dan sehat. Fasilitas kesehatan primer dan rujukan berperan penting dalam tatalaksana ba;ita sakit sesuai standar.

6. Dukungan lintas sector

Hal ini diperluakan dalam pemenuhan kebutuhan air bersih dana tau pengadaan jamban keluarga, serta lingkungan sehat dalam uoaya pencegahan penyakit 
infeksi berulang yang dapat emngakibatkan gizi buruk pada balita. Demikian pula dalam pengaturan makanan/ cemilan yang sehat untuk anak.

7. Perhatian khusus diberikan kepada balita yang rentan memiliki gizi buruk, melalui berbagai intervensi untuk pencegahan masalah gizi seperti tercakup dalam upaya "seribu hari pertama dalam kehidupan".

\section{KESIMPULAN}

1. Masalah gizi karena kemiskinan indikatornya taraf ekonomi keluarga dan ukuran yang dipakai adalah garis kemiskinan.

2. Masalah gizi karena sosial budaya indikatornya adalah stabilitas keluarga dengan ukuranfrekuensi nikah-cerai-rujuk, anak-anak yang dilahirkan di lingkungan keluarga yang tidak stabil akan sangat rentan terhadap penyakit gizi-kurang. Juga indikator demografi yang meliputi susunan dan pola kegiatan penduduk.

3. Masalah gizi karena kurangnya pengetahuan dan keterampilan di bidang memasak, konsumsi anak, keragaman bahan, dan keragaman jenis masakan yang mempengaruhi kejiwaan, misalnya kebosanan.

4. Masalah gizi karena pengadaan dan distribusi pangan, indikatorpengadaan pangan (food supply) yang biasanya diperhitungkan dalam bentuk neraca bahan pangan, diterjemahkan ke dalam nilai gizi dan dibandingkan dengan nilai rata-rata kecukupan penduduk.

Gangguan kesehatan,walau hanya gangguan kecil dapat menghambat belajar anak,misalnya diare,diare akan membuat badan si anak lemasdan tidak akan sedikit yang mengantarkan mereka pada kematian karena kekurangan cairan.Gizi yang juga akan mengganggu kesehatan anak,jika gizi yang buruk terjadi pada anak usia dini,maka akan mengakibatkan terganggunya kinerja otak bahkan mengurangi kapasitas kecerdasan anak. Bukan berarti makanan yang enak itu dapat memenuhi gizi seimbang,tetapi makanan dengan gizi seimbang adalah makanan yang mengandung karbohidrat,protein,lemak,vitamin,dan mineral dengan kadar yang sesuai dengan kebutuhan tubuh anak. Jadi kebutuhan gizi yang seimbang pada anak usia dini sangatlah penting dan haruslah terpenuhi sesuai kebutuhan masing-masing anak.Karena dengan kebutuhan gizi yang cukup,anak akan tumbuh dan berkembang dengan baik dan pesat. Dan hal tersebut haruslah menjadi perhatian utama bagi orang tua dan tidak boleh disepelekan.

\section{DAFTAR PUSTAKA}

Abdillah, Suratman Fajar.CAGI Pediatric (Catatan Ahli Gizi Indonesia),Azura.2017

Almatsier, S. Prinsip Dasar Ilmu Gizi. Gramedia Pustaka Utama, Jakarta, 2001.

Auliyah, Ikrima.Kesehatan Anak dan Balita By Ikrima Aulia Rustam,2021.

Departemen Gizi dan Kesehatan Masyarakat FKM UI.Gizi dan Kesehatan Masyarakat.jakarta : PT Raja Grafindo Persada, 2010. 
Detik news, 9 juta anak kekurangan gizi. Retrieved from https//.mdetik.com

Energi dan Zat Gizi dalam Penyelenggaraan Makanan di Taman Kanak-Kanak dan Perbandingannya Terhadap Subjek Tanpa Penyelenggaraan Makanan. Jurnal Gizi dan Pangan. Vol 12 (1), 69 -78. http://dx.doi.org/10.25182/jgp.2017 12.1.6978. Hariza Adnani. Ilmu Kesehatan Masyarakat.Yogyakarta Nuha Medika. 2011 $\mathrm{http} /$ /yanamustakim.blogspot.com

Hariza Adnani,2011.Ilmu Kesehatan Masyarakat.Yogyakarta Nuha Medika.

Indriani, R, Mesiono, Sapri. (2019). Intensitas Asupan Gizi dalam Mengembangkan Kesehatan Anak Usia 5-6 Tahun di TK Ummi Erni Desa Pematang Johar. Jurnal Raudhah. Vol 7 (2). $35-48$.

Indriani, R, Mesiono, Sapri. (2019). Intensitas Asupan Gizi dalam Mengembangkan

Kesehatan Anak Usia 5-6 Tahun di TK Ummi Erni Desa Pematang

Johar. Jurnal Raudhah. Vol 7 (2). 35 - 48.

Komara, Iin, and Nurbayani Nirmala Putri. "Upaya meningkatkan pengetahuan gizi anak usia dini melalui parenting." Journal on Education 1.4 (2019).

Kementrian Kesehatan RI. Direktur jendral kesehatan bina gizi dan kesehatan Ibu dan Balita,2014.

Kementerian Kesehatan RI. Laporan Nasional HasilRiset Kesehatan Dasar 2018. Jakarta: Kemenkes RI; 2018.

Marzali, A. (2016). Menulis Kajian Literatur. Jurnal Etnosia. Vol 1 (2), 27 - 36. 10.31947/etnosia.v1i2.1613

Riady B.dody,Arinah Habibah Fitriyah.Dasar-Dasar manajemen dalam pendidikan gizi.Refika,2018.

Syafiq, Ahmad. "Tinjauan atas kesehatan dan gizi anak usia dini." Makalah pada Diskusi Peningkatan Kesehatan dan Gizi Anak Usia Dini, Bappenas. Jakarta: Departemen Gizi Kesehatan Masyarakat, FKMUI (2007).

Kurnia, R. Pendidikan Gizi Untuk Anak Usia Dini. Jurnal Educhild: Pendidikan dan Sosial, 4.22014 .

Titah nurul lathifah tahar, Status gizi balita. Jurnal ilmiah kesehatan 7 (1), 1-8, 2018 Program Studi Gizi, Fakultas Kedokteran dan Ilmu Kesehatan, Universitas Kristen Satya Wacana. Jl. Kartini No.11 A, Salatiga, Jawa Tengah 50711, Indonesia

Jurnal Gizi Indonesia (The Indonesian Journal of Nutrition), 8 (2), 2020, 143 